\title{
ANALISIS KEBIJAKAN PEMERINTAH DALAM MENETAPKAN IBUKOTA KABUPATEN KERINCI DI BUKIT TENGAH
}

\author{
Mario Dirgantara \\ mariodirgantara@ymail.com
}

\begin{abstract}
The establishment of autonomous regions is one of the government efforts to bring public service closer to people. Every new autonomous regions are expected to create synergy with their parent regions. The proliferation of new administrative areas also requires the establishment of new capitals which will become the icon of the area. This is where all public services and trade activities will be centralized. After the decision to proliferate the Kerinci Regency being made, the new capital of Kerinci has been moved to Bukit Tengah, Siulak. Using the qualitative descriptive method, this research presents the indicators that become the point of reference of Kerinci Regency's government in deciding the location of the new administrative capital.
\end{abstract}

Keywords: public policy, public service

\begin{abstract}
Abstrak
Pembentukan daerah otonomi baru merupakan salah satu upaya pemerintah untuk mendekatkan pelayanan kepada masyarakat. Setiap daerah otonomi baru, diharapkan mampu bersinergi dengan daerah induk hasil pemekaran. Setiap pembentukan daerah otonomi baru, tentunya akan menimbulkan pembentukan ibukota daerah baru dari hasil pemekaran, karena ibukota sebuah daerah nantinya akan menjadi pusat pelayanan publik, jasa dan perdagangan. Kabupaten Kerinci setelah dimekarkan menetapkan ibukota kabupaten Kerinci yang baru di Bukit Tengah Siulak. Penelitian ini bertujuan untuk membahas indikator-indikator yang menjadi acuan pemerintah kabupaten Kerinci dalam menetapkan pusat pemerintahannya. Metode yang digunakan dalam penelitian ini adalah deskriptif kualitatif.
\end{abstract}

Kata kunci : Kebijakan publik, pelayanan publik 


\section{PENDAHULUAN}

Pembentukan daerah otonomi baru pada dasarnya di maksudkan untuk meningkatkan pelayanan publik guna mempercepat terwujudnya kesejahteraan masyarakat di samping sebagai sarana pendidikan politik di tingkat lokal. Untuk itu maka pembentukan daerah harus mempertimbangkan berbagai faktor seperti kemampuan ekonomi, potensi daerah, luas wilayah,kependudukan dan pertimbangan dari aspek sosial politik, sosial budaya, pertanahan dan keamanan serta pertimbangan dan syarat lainnya yang memungkinkan daerah itu dapat menyelenggarakan dan mewujudkan tujuan di bentuknya nya daerah dan di berikannya otonomi daerah.

Undang-Undang no 25 tahun 2008 menetapkan Kota Sungai Penuh sebagai kota baru dan terpisah secara administratif dari Kabupaten Kerinci. Dengan demikian kota Sungai Penuh yang dulunya merupakan Ibukota Kabupaten kerinci tidak lagi menjadi Ibukota Kabupaten Kerinci. Kota Sungai Penuh berasal dari sebagian wilayah Kabupaten Kerinci yang terdiri dari :

a. Kecamatan Sungai Penuh

b. Kecamatan Pesisir Bukit

c. Kecamatan Hamparan Rawang

d. Kecamatan Tanah Kampung

e. Kecamatan Kumun Debai

Dengan disetujuinya Kota Sungai Penuh sebagai daerah otonomi baru setelah pemekaran, maka kota Sungai Penuh tidak lagi menjadi Ibukota Kabupaten kerinci. Dengan demikian, Kabupaten Kerinci harus segera menentukan ibukota baru sebagai sentra pelayanan publik yang dapat diakses dengan mudah oleh semua lapisan masyarakat. Hal tersebut dikarenakan seluruh proses pelayanan publik Kabupaten Kerinci selama ini terpusat di Kota Sungai Penuh yang dulunya merupakan Ibukota Kabupaten Kerinci. Sehingga Pemerintah Kabupaten Kerinci harus segera menentukan ibukota Kabupaten Kerinci yang baru sebagai pengganti Kota Sungai Penuh sebagai sentral publik untuk melaksanakan pelayanan kepada masyarakat, pusat pengendalian dan pertumbuhan pengembangan, dan jasa-jasa sosial lainnya.

Berdasarkan dari indikator-indikator yang ditetapkan oleh LAPI ITB dan BAPPENAS, Ibukota Kabupaten Kerinci yang baru harus bisa memenuhi kriteria-kriteria sebagai pusat kegiatan administratif seperti kemampuan ekonomi, potensi daerah, kependudukan, luas daerah, pertahanan, keamanan, kemampuan keuangan, tingkat kesejahteraan masyarakat dan rentang kendali penyelenggaraan pemerintahan. Selain itu, tata ruang, arsitektur, geologi, infrastruktur, sosial ekonomi, pengembangan daerah lokasi ibukota kabupaten juga menjadi indikator dalam menentukan lokasi tersebut. Dari kriteria yang ada, maka didapatkan beberapa daerah nominasi yang akan menjadi calon ibukota kabupaten Kerinci dengan indikator-indikator yang ditetapkan diantaranya kemudahan dalam menemukan kantor, kerawanan lokasi terhadap bencana, aspek legalitas (meliputi kepemilikan lahan,potensi konflik kepemilikan lahan), ketersediaan lahan untuk pembangunan jangka panjang, dll. Namun setelah diajukannya Bukit Tengah Siulak menjadi calon ibukota Kabupaten Kerinci berdasarkan surat keputusan DPRD Kabupaten Kerinci nomor 13 tahun 2010 yang menindak lanjuti keputusan bupati Kerinci no 135.5/Kep.203/2010, maka lokasi Ibukota Kabupaten Kerinci yang baru pun di tetapkan dibukit tengah kecamatan siulak. Dari hasil kajian yang dilakukan oleh LAPI ITB, bukit tengah siulak tidak termasuk dalam 
daerah nominasi. Hasil kajian dari LAPI ITB adalah di daerah Bukit Cuguk, kemantan darat, sungai tutung, dan pendung hilir. Namun pada kajian yang dilakukan oleh Bappenas, daerah nominasi untuk menjadi ibukota Kabupaten adalah daerah Sitinjau laut, Air hangat, Siulak, Air hangat timur. Nilai tertinggi dalam penelitian yang dilakukan oleh bappenas adalah kecamatan siulak. Dan dari indikator yang di di tetapkan oleh Bappenas, pengadaan lahan lah yang mempunyai nilai tertinggi dikecamatan Siulak dibandingkan dengan daerah lain. Namun pada indikator-indikator yang lain yang ditetapkan Bappenas, penilaian pada lokasi-lokasi lain masih seimbang dengan kecamatan Siulak.

\section{METODE PENELITIAN}

Jenis penelitian ini menggunakan metode Deskriptif Kualitatif. Menurut Soehardi Sigit $(2001 ; 224)$ Penelitian Deskriptif menentukan dan melaporkan keadaan yang ada menurut kenyataannya, dengan mengukurnya. Penelitian deskriptif hanya melaporkan keadaan yang sesungguhnya ada. Penelitian deskriptif yang tipikal ialah untuk mengetahui sikap, pendapat (opini), informasi demografi, keadaann dan prosedur. Ulber Silalahi menjelaskan dalam bukunya metode penelitian sosial (2009:272) tentang purposive sampling atau pemilihan sampel purposive merupakan pemilihan subjek yang ada dalam posisi terbaik untuk memberikan informasi yang dibutuhkan.Karena itu, menetukan subjek atau orang-orang terpilih harus sesuai dengan ciri-ciri khusus yang dimiliki oleh sampel itu. Mereka dipilih karena dipercaya mewakili satu populasi tertentu. Pilihan atas sampel purposive karena peneliti menguji pertimbangan-pertimbangannya untuk memasukkan unsur atau subjek yang dianggap khusus dari suatu populasi tempat dia mencari informasi. Subjek penelitian adalah Kepala Bappeda, Kepala bagian pemerintahan, anggota DPRD, masyarakat. Teknik pengumpulan data dalam penelitian ini menggunakan (1)wawancara, (2)observasi dan (3)dokumentasi. Peneliti sebagai instrument maka melakukan validasi dengan cara memahami metode dan objek penelitian. Teknik analisis data menggunakan model penelitian kualitatif versi Miles dan Huberman yaitu dengan reduksi data, display data, kesimpulan dan verifikasi. Sedangkan untuk mengecek keabsahan data menggunakan tiangulasi sumber.

\section{HASIL DAN PEMBAHASAN}

Setelah diadakan penelitian dan pengumpulan data di lapangan melalui wawancara, observasi lapangan serta menganalisa sumber yang telah ada, maka diperoleh data dari informan atau responden terkait penetapan ibukota Kabupaten Kerinci di Bukit Tengah Siulak.

Penetapan Ibukota Kabupaten Kerinci di Bukit Tengah Siulak telah mengundang banyak perdebatan dan tanda tanya dari masyarakat. Hasil Keputusan dari DPRD kabupaten Kerinci no 13 tahun 2010 pada tanggal 14 juni 2010 telah mengesahkan bahwa Ibukota Kabupaten Kerinci yang baru adalah Bukit tengah Kecamatan Siulak. Lahan hibah yang di berikan oleh masyarakat Adat Tigo Luhah Tanah Sekudung di Bukit Tengah Siulak adalah seluas $300 \mathrm{Ha}$.

Penetapan Ibukota kabupaten Kerinci yang baru dikarenakan terbentuknya kota otonom Sungai Penuh yang berdasarkan Undang-Undang nomor 25 tahun 2008 tentang pembentukan kota Sungai Penuh di Provinsi Jambi. Sebelum keluarnya UU nomor 25 tahun 2008, Ibukota kabupaten Kerinci ditetapkan di Renah Pemetik sebagai calon ibukota kabupaten sesuai dengan keputusan Buapti Kerinci nomor 135.7/Kep 31 /2007 tentang 
penetapan lokasi calon ibukota Kabupaten Kerinci di Renah Pemetik dan dilanjutkan dengan keputusan ketua DPRD Kerinci nomor 7 tahun 2007 tentang Persetujuan Penetapan Lokasi Calon Ibukota Kabupaten Kerinci di Renah Pemetik. Namun ketetapan itu bukanlah ketetapan final, karena pada keputusan itu juga di cantumkan pada diktum kedua bahwa keputusan secara defenitif akan ditetapkan setelah selesainya studi kelayakan oleh konsultan profesional dan independen dan selanjutnya akan di tetapkan dengan keputusan DPRD Kabupaten Kerinci. Konsultan profesional ini adalah lembaga yang akan meneliti dan mengkaji lokasi alternatif untuk Ibukota Kabupaten Kerinci. LAPI ITB merupakan satu-satunya lembaga konsultan yang mendaftarkan diri untuk menjadi konsultan dalam menetapkan alternatif lokasi ibukota Kabupaten Kerinci. Berdasarkan surat keputusan penetapan pemenang penunjukan langsung kegiaatan penelitian rencana ibukota Kabupaten Kerinci tahun anggaran 2008 nomor 050/309/IV/Bappeda. Penilitian juga dilakukan oleh Bappenas yang bekerjasama dengan Pemerintah Kabupaten kerinci. Penelitian yang dilakukan oleh Bappenas di dasari oleh surat undangan yang dikirimkan oleh Bupati Kerinci nomor 050/049/1/2009 sebagai peneliti lokasi alternatif ibukota Kabupaten Kerinci. Dari hasil kajian yang dilakukan oleh LAPI ITB dan Bappenas, maka didapatkan daerah nominasi yang nantinya akan dipilih untuk menjadi ibukota Kabupaten Kerinci. Setelah mengevaluasi hasil yang dikeluarkan oleh LAPI ITB dan Bappenas, maka pemerintah kabupaten Kerinci mengeluarkan surat keputusan Bupati Kerinci nomor 135.5/Kep.230/2010 yang berisikan tentang penetapan ibukota kabupaten Kerinci di Bukit Tengah Kecamatan Siulak. Hasil dari surat keputusan ini di kaji oleh DPRD Kabupaten Kerinci melalui rapat paripurna DPRD kabupaten Kerinci tanggal 14 Juni 2010. Dari hasil rapat paripurna yang dilakukan oleh DPRD nomor 13 tahun 2010 tentang Persetujuan penetapan Calon ibukota Kabupaten Kerinci Provinsi Jambi, maka di tetapkanlah ibukota kabupaten Kerinci di Bukit Tengah Siulak dengan pertimbangan bahwa lahan untuk pembangunan kantor merupakan lahan hibah yang di berikan oleh masyarakat adat tigo luhah tanah sekudung. Lahan tersebut dihibahkan dengan luas sebesar 300 Ha. Lokasi pembangunan perkantoran juga dapat di bangun pada lokasi lain dalam wilayah kabupaten Kerinci yang tanahnya di hibahkan oleh masyarakat. Dengan keluarnya keputusan ini, maka keputusan Pimpinan DPRD Kabupaten Kerinci no 7 tahun 2007 tentang penetapan lokasi ibukota kabupaten Kerinci di Renah Pemetik, dicabut dan dinyatakan tidak berlaku lagi.

Hasil kajian dari Lembaga Afiliasi Peneliti dan Industri( LAPI ) ITB juga ikut memberikan masukan untuk lokasi Ibukota Kabupaten Kerinci. Dari hasil kajian yang dilakukan oleh LAPI ITB, empat kecamatan yang dipilih untuk calon lokasi Ibukota Kabupaten Kerinci adalah Bukit Cuguk, Kemantan Darat, Sungai Tutung, dan Pendung Hilir. Dari keempat calon Ibukota Kabupaten Kerinci yang diusulkan oleh LAPI ITB, jelas terlihat bahwa Bukit Tengah Siulak bukan merupakan daerah nominasi untuk dijadikan Ibukota Kabupaten Kerinci. Kajian yang dilakukan oleh LAPI ITB di dasarkan atas penilaian yang meliputi tata ruang, Arsitektur, Geologi, Infrastruktur, Sosial ekonomi dan Pengembangan.

\section{Parameter Penilaian Calon Ibukota Kabupaten Kerinci}

\begin{tabular}{|l|l|l|} 
Parameter & Bobot & Keterangan \\
\hline
\end{tabular}




\begin{tabular}{|c|c|c|c|}
\hline $\mathrm{a}$ & $\begin{array}{l}\text { Aksesibilitas } \\
\text { / Kemudahan } \\
\text { Pelayanan }\end{array}$ & 10 & $\begin{array}{l}\text { Sangat } \\
\text { penting } \\
\text { mengingat } \\
\text { ibukota } \\
\text { kabupaten } \\
\text { digunakan } \\
\text { oleh banyak } \\
\text { pihak dalam } \\
\text { waktu yang } \\
\text { cukup lama }\end{array}$ \\
\hline $\mathrm{b}$ & $\begin{array}{l}\text { Kesesuaian } \\
\text { terhadap } \\
\text { Zona }\end{array}$ & 10 & $\begin{array}{l}\text { Pengembang } \\
\text { an yang } \\
\text { bersifat } \\
\text { strategis } \\
\text { haruslah } \\
\text { sejalan } \\
\text { dengan zona } \\
\text { pengembang } \\
\text { an RTRW }\end{array}$ \\
\hline $\mathrm{c}$ & $\begin{array}{l}\text { Hubungan } \\
\text { dengan } \\
\text { Ibukota } \\
\text { Provinsi }\end{array}$ & 10 & $\begin{array}{l}\text { Sebagai } \\
\text { ibukota } \\
\text { kabupaten } \\
\text { sebaiknya } \\
\text { memiliki } \\
\text { hubungan } \\
\text { dengan } \\
\text { ibukota } \\
\text { provinsi } \\
\text { sebagai } \\
\text { acuan } \\
\text { pengembang } \\
\text { an kabupaten }\end{array}$ \\
\hline $\mathrm{d}$ & Representatif & 10 & $\begin{array}{l}\text { Sebagai } \\
\text { ibukota } \\
\text { kabupaten } \\
\text { memiliki } \\
\text { lokasi yang } \\
\text { representatif } \\
\text { terhadap } \\
\text { kabupatenny } \\
\text { a. }\end{array}$ \\
\hline $\mathrm{e}$ & View & 5 & $\begin{array}{l}\text { Sebagai } \\
\text { kantor } \\
\text { sebaiknya } \\
\text { memiliki }\end{array}$ \\
\hline
\end{tabular}




\begin{tabular}{|c|c|c|c|}
\hline & & & $\begin{array}{l}\text { view yang } \\
\text { baik. }\end{array}$ \\
\hline $\mathrm{f}$ & $\begin{array}{l}\text { Rawan } \\
\text { Bencana } \\
\text { gempa }\end{array}$ & 10 & $\begin{array}{l}\text { Calon lokasi } \\
\text { haruslah } \\
\text { aman dari } \\
\text { bencana alam } \\
\text { gempa } \\
\text { sehingga } \\
\text { sangat } \\
\text { penting } \\
\text { lokasi } \\
\text { ibukota } \\
\text { berada pada } \\
\text { kondisi } \\
\text { geologi } \\
\text { dengan } \\
\text { resiko } \\
\text { bencana alam } \\
\text { yang lebih } \\
\text { kecil }\end{array}$ \\
\hline $\mathrm{g}$ & $\begin{array}{l}\text { Daya dukung } \\
\text { Tanah }\end{array}$ & 10 & $\begin{array}{l}\text { Perlu } \\
\text { mendapatkan } \\
\text { perhatian } \\
\text { mengingat } \\
\text { hal ini dapat } \\
\text { membatasi } \\
\text { jumlah lantai } \\
\text { dan } \\
\text { menaikkan } \\
\text { biaya } \\
\text { konstruksi } \\
\text { untuk } \\
\text { perbaikan } \\
\text { kualitas tanah }\end{array}$ \\
\hline $\mathrm{h}$ & $\begin{array}{l}\text { Pengadaan } \\
\text { air bersih }\end{array}$ & 10 & $\begin{array}{l}\text { Dengan } \\
\text { kondisi yang } \\
\text { ada } \\
\text { pengadaan } \\
\text { air tidak } \\
\text { terlalu } \\
\text { menjadi } \\
\text { maslah }\end{array}$ \\
\hline $\mathrm{i}$ & $\begin{array}{l}\text { Distribusi } \\
\text { Listrik }\end{array}$ & 5 & $\begin{array}{l}\text { Dengan } \\
\text { kondisi yang } \\
\text { ada }\end{array}$ \\
\hline
\end{tabular}




\begin{tabular}{|c|c|c|c|}
\hline & & & $\begin{array}{l}\text { pengadaan } \\
\text { listrik tidak } \\
\text { terlalu } \\
\text { menjadi } \\
\text { masalah }\end{array}$ \\
\hline $\bar{j}$ & $\begin{array}{l}\text { Kepemilikan } \\
\text { lahan }\end{array}$ & 5 & $\begin{array}{l}\text { Mengingat } \\
\text { kebutuhan } \\
\text { sangat } \\
\text { mendesak , } \\
\text { maka } \\
\text { kemudahan } \\
\text { penyiapan } \\
\text { lahan sangat } \\
\text { penting, } \\
\text { sangat } \\
\text { penting jika } \\
\text { hanya } \\
\text { dikuasai oleh } \\
\text { sedikit pihak } \\
\text { atau badan } \\
\text { usaha }\end{array}$ \\
\hline $\mathrm{k}$ & $\begin{array}{l}\text { Kondisi } \\
\text { Lingkungan } \\
\text { masyarakat }\end{array}$ & 5 & $\begin{array}{l}\text { Kondisi } \\
\text { lingkungan } \\
\text { di sekitar } \\
\text { lokasi } \\
\text { menjadi } \\
\text { penting } \\
\text { dalam hal } \\
\text { representatif } \\
\text { dan citra dari } \\
\text { perkantoran } \\
\text { ini juga } \\
\text { dibentuk oleh } \\
\text { lingkungan } \\
\text { sekitar }\end{array}$ \\
\hline 1 & $\begin{array}{l}\text { Ketersediaan } \\
\text { lahan }\end{array}$ & 10 & $\begin{array}{l}\text { Adanya lahan } \\
\text { bagi } \\
\text { pembanguna } \\
\text { n ibukota dan } \\
\text { lahan lahan } \\
\text { bagi } \\
\text { pengembang } \\
\text { an ibukota } \\
\text { sangat } \\
\text { penting }\end{array}$ \\
\hline
\end{tabular}




\begin{tabular}{|c|c|c|c|}
\hline & & & $\begin{array}{l}\text { dimiliki pada } \\
\text { lokasi } \\
\text { ibukota } \\
\text { kabupaten }\end{array}$ \\
\hline $\mathrm{m}$ & $\begin{array}{l}\text { Ketahanan } \\
\text { terhadap } \\
\text { banjir }\end{array}$ & 5 & $\begin{array}{l}\text { Akan } \\
\text { berkaitan } \\
\text { dengan } \\
\text { potensi banjir } \\
\text { yang ada } \\
\text { pada daerah } \\
\text { calon lokasi }\end{array}$ \\
\hline $\mathrm{n}$ & $\begin{array}{l}\text { Potensi } \\
\text { pengembang } \\
\text { an }\end{array}$ & 5 & $\begin{array}{l}\text { Lokasi } \\
\text { ibukota } \\
\text { kabupaten } \\
\text { baru akan } \\
\text { menghadapi } \\
\text { tantangan } \\
\text { pengembang } \\
\text { an kawasan } \\
\text { yang lebih } \\
\text { luas, } \\
\text { sehingga } \\
\text { perlu adanya } \\
\text { penilaian } \\
\text { terhadap } \\
\text { potensi } \\
\text { berkembangn } \\
\text { ya suatu } \\
\text { kawasan } \\
\text { hingga } 1000 \\
\text { Ha. }\end{array}$ \\
\hline
\end{tabular}

Sumber : Final Report LAPI ITB

Hasil pembahasan pada penelitian ini haruslah memperhatikan beberapa aspek untuk menentukan lokasi Ibukota Kabupaten Kerinci dengan indikator :

1.Aksebilitas

Aksebilitas merupakan faktor penting bagi sebuah ibukota. Dengan adanya aksebilitas yang baik pada ibukota baru kabupaten dapat dicapai oleh berbagai pihak dalam upaya pelayanan terhadap masyarakat. Sehingga kemudahan aksebilitas akan mendorong percepatan pembangunan dan pengembangan suatu ibukota.

2.Ketersediaan lahan

Ketersediaan lahan berkaitan dengan pembangunan pada ibukota dalam membangun berbagai fungsi kawasan dalam ibukota seperti transportasi, perdagangan, pemerintahan, dan permukiman.

3. Ketersediaan infrastruktur 
Ketersediaan sarana dan prasarana berkaitan dengan kemampuannya dalam mendukung perkembangan kota. Prasarana meliputi tingkat pelayanan air bersih, listrik dan telekomunikasi.

\section{Potensi Pengembangan Kawasan}

Lokasi Ibukota kabupaten baru akan menghadapi tantangan pengembangan kawasan yang lebih luas, sehingga perlu adanya penilaian terhadap potensi berkembangnya suatu kawasan hingga $1000 \mathrm{Ha}$.

5.Kondisi Geologi - Kesesuaian Lahan

Aspek Geologis digunakan untuk mengidentifikasi kesesuaian lahan untuk pembangunan infrastruktur dalam bidang transportasi, perdagangan, pemerintahan, dan permukiman. Disamping itu aspek kesesuaian lahan ini digunakan untuk melakukan mitigasi terhadap daerah rawan bencana alam terutama gempa bumi dan banjir sehingga lokasi ibukota kabupaten yang baru yang diajukan dapat terhindar dari daerah tersebut.

6.Kesesuaian terhadap Zona

Kesesuaian terhadap Zona merupakan penilaian kesesuaian pengembangan lokasi terhadap RTRW

7.Keterkaitan terhadapa daerah sekitarnya

Timbal balik antara Ibukota baru tersebut dengan kabupaten induk, serta hubungannya dengan daerah sekitarnya.Hubungan tersebut meliputi perdagangan, pemerintahan, dan sosial budaya serta dampak yang di timbulkan.

8.Pembebasan Lahan

Kemudahan Penyiapan lahan sangat penting, mengingat pembangunan lokasi ibukota perlu segera ditetapkan. Sehingga sangat ideal jika kepemilikan lahan hanya dikuasai sedikit pihak atau badan usaha.

1.Aspek pengembangan

Hal ini juga perlu mendapatkan perhatian dari awal, mengingat Kabupaten Kerinci sebagai kabupaten pemekaran baru akan cepat sekali mengalami pertumbuhan yang nantinya harus di fasilitasi.

2.Aspek estetika ( View )

Lokasi representatif sebagai pusat pemerintahan adalah tempat yang sesuai untuk pelayanan pada masyarakat dan mampu mencerminkan atau sebagai simbol pusat pemerintahan dilihat segi tata ruang.View yang baik adalah situasi pandangan terhadap lingkungan sekitarnya mampu memberikan dampak positif terhadap aktivitas maupun manusia yang ada didalamnya.

Berdasarkan hasil penelitian kelapangan dan wawancara mendalam dengan informan yang telah ditetapkan, penetapan ibukota Kabupaten Kerinci sekarang di Bukit tengah Siulak ini mendapat penolakan oleh sebagian masyarakat Kerinci bagian hilir. Hal ini dikarenakan oleh jauhnya jarak yang akan ditempuh oleh masyarakat Kerinci hilir untuk menuju lokasi Ibukota Kabupaten Kerinci. Anggota DPRD kabubapen Kerinci menjelaskan bahwa penolakan masyarakat itu dikarenakan akses jalan menuju Ibukota Kabupaten tidak begitu baik, itulah yang menyebabkan jarak antara masyarakat Kerinci hilir untuk menuju Ibukota Kabupaten Kerinci terasa jauh. Jika jalan sudah baik dan mulus, pastinya waktu yang diperlukan untuk menuju lokasi Ibukota Kabupaten Kerinci tidak lama. Penulis juga menanyakan tentang kelayakan Bukit tengah menjadi Ibukota Kabupaten Kerinci, Anggota DPRD Kabupaten Kerinci juga menjelaskan bahwa hampir 
semua alternatif lokasi yang di pilih itu merupakan daerah yang baik. Namun Cuma di Bukit Tengah yang disediakan lahan hibah, sehingga dipilih lah ibukota Kabupaten Kerinci di Bukit Tengah kecamatan Siulak. Penulis juga melakukan observasi dan melakukan wawancara dengan kepala desa di sekitar bukit Cuguk, dari hasil wawancara di ketahui bahwa masyarakat pemilik lahan didaerah bukit Cuguk memang tidak bersedia menghibahkan lahannya. Masyarakat pemilik tanah di Bukit Cuguk itu meminta pemerintah daerah untuk ganti rugi lahan tanah yang akan dibangun pemerintah sebagai Ibukota Kabupaten Kerinci. Kades koto Salak, Hardi juga menerangkan bahwa tanah pada bukit Cuguk ini merupakan tanah pribadi warga dan dimiliki oleh sebagian penduduk yang ada di sekitar pinggiran bukit Cuguk. Lebih lanjut, kades koto Salak juga menjelaskan bahwa bukit Cuguk digunakan masyarakat sekitar untuk berkebun. Otomatis lahan tersebut merupakan salah satu sumber mata pencaharian masyarakat sekitar.

Penetapan Bukit Tengah Siulak menjadi ibukota Kabupaten Kerinci ini berdasarkan pada keputusan bupati Kerinci nomor 135.5/Kep.230/2010 dan dilanjutkan dengan hasil rapat paripurna DPRD kabupaten Kerinci no 13 tahun 2010 tanggal 14 Juni 2010 dalam rangka penetapan keputusan DPRD tentang persetujuan penetapan calon ibukota Kabupaten Kerinci.

Berdasarkan hasil wawancara dengan pihak bappeda yaitu bapak Hans Moravia, Bukit Tengah Siulak nantinya akan dijadikan sebagai kawasan perkantoran, pemukiman dan perumahan warga. Dan untuk kawasan jasa dan perdagangan akan di tempatkan pada daerah-daerah lain di kabupaten Kerinci sesuai dengan potensi kewilayahan. Pembagian kawasan-kawasan ini bertujuan untuk menghidupkan perekonomian masyarakat di seluruh sektor di kabupaten Kerinci.

Dari hasil wawancara dengan stakeholder kunci dan observasi lapangan yang penulis lakukan, penetapan ibukota Kabupaten Kerinci di Bukit Tengah Siulak ini didasari oleh beberapa faktor-faktor diantara lain meliputi :

a. Aspek Aksesibilitas

Ibukota Kabupaten Kerinci di Bukit Tengah Siulak merupakan lokasi yang terletak sekitar $2 \mathrm{Km}$ dari jalan provinsi. Jarak tersebut di dapat jika akses jalan masuk melalui desa Koto Pegeh, langsung menuju lokasi Bukit Tengah. Jika dilihat dari peta kabupaten Kerinci, jarak masyarakat dari hilir memang cukup jauh untuk mencapai ibukota Kabupaten Kerinci yang baru. Ditambah lagi lokasi yang berada di daerah perbukitan, sehingga untuk mengetahui lokasi perkantoran, harus dengan meminta petunjuk dari masyarakat sekitar. Karena persimpangan untuk menuju lokasi ibukota tidak begitu terlihat dengan jelas.

b. Aspek Ekologis

Melihat dari aspek Ekologis atau kondisi fisik lahan, secara keseluruhan lokasi ini cukup baik untuk wilayah perkantoran. Namun banyak terdapat lokasi-lokasi tertentu yang kondisi tanah nya tidak baik untuk dijadikan perkantoran. Pada lokasi pembangunan kantor bupati di bukit tengah, penulis menemukan kondisi tanah yang tidak stabil, dan kemungkinan besar jika tetap di bangun pada lokasi itu, maka bencana longsor kemungkinan dapat terjadi. Sebab pada area ini memiliki jurang yang cukup suram. Ditambah lagi dengan kawasan di sekitar lokasi perkantoran masyarakat telah banyak menebang pohon-pohon dan tanaman yang bisa menjadi resapan air hujan. Hans Moravia dari pihak Bappeda juga menjelaskan bahwa untuk lokasi perkantoran yang akan dibangun 
merupakan wilayah yang aman dari bencana longsor, Cuma memang ada di beberapa titik yang tidak layak untuk dibangun perkantoran. Dan daerah yang tidak layak itu tidak akan dibangun perkantoran. Jika dilihat dari sudut kemiringan tanah, lokasi untuk perkantoran akan dipilih lokasi terbaik dan aman dari bencana longsor.

c. Aspek Eksisting Infrastruktur

Dari hasil observasi ke lapangan, diketahui bahwa akses menuju lokasi ibukota Kabupaten Kerinci di Bukit Tengah saat ini kurang layak, jalan yang digunakan sempit dan berbatu. Jalan dari desa mukai tinggi menuju lokasi ibukota masih jalan tanah yang baru di buka. Jalan ini merupakan satu-satunya jalan menuju lokasi ibukota kabupaten. Namun pihak pemerintah daerah telah berencana untuk membangun akses jalan desa koto pegeh menuju bukit Tengah, sehingga nantinya melalui jalan ini akan dapat dengan mudah dicapai masyarakat. Untuk akses seperti listrik, air dan telepon belum ada pada lokasi ini, Bupati Kerinci Murasman menjelaskan bahwa Pemerintah daerah berencana untuk membangun Pembangkit Listrik Tenaga Air (PLTA) dari sumber air terjun yang berada dengan jarak sekitar $6 \mathrm{Km}$ dari lokasi pembangunan kantor pemerintah. PLTA ini di bangun untuk memenuhi kebutuhan listrik daerah perkantoran di bukit tengah siulak ini. PLTA yang akan dibangun diperkirakan akan menelean dana sekitar 18 Miliar rupiah. Disamping itu untuk kebutuhan terhadap air bersih, juga akan dibangun bak penampungan di sekitar air terjun ini, dan akan dialirkan ke kantor-kantor yang ada di bukit tengah. Pengadaan terhadap air bersih itu di telah diajukan pihak PDAM untuk dianggarkan pada APBD tahun 2011 dengan total anggaran sebesar 15 miliar rupiah

d. Aspek ekonomi

Dari hasil wawancara dengan bapak hans Moravia dari Bappeda Kabupaten Keirnci, di ketahui bahwa bidang ekonomi, sektor jasa dan perdagangan tidak difokuskan pada wilayah Bukit Tengah. Wilayah Bukit tengah hanya di fokuskan untuk wilayah perkantoran. Untuk bidang perekonomian, jasa dan perdagangan wilayah siulak gedang, semurup dan belui yang nantinya diharapkan bisa berkembang untuk sektor ini. Mata pencaharian masyarakat di sekitar ibukota kabupaten Kerinci sangat beragam, namun lebih dominan masyarakat yang bekerja di bidang pertanian. Masyarakat di sekitar lokasi jalan menuju bukit tengah, lebih didominasi dengan petani kulit manis dan sawah. Namun kebun kulit manis tidak begitu dominan di tanam di daerah ini, karena sebagian masyarakat sekitar Bukit tengah mempunyai lahan kebun di daerah lain seperti Kayu Aro dan Renah Pemetik. e. Aspek Legalitas

Lahan untuk menjadi ibukota kabupaten Kerinci merupakan lahan hibah dari masyarakat adat tigo luhah tanah sekudung. Lahan ini di hibahkan oleh masyarakat untuk pembangunan ibukota kabupaten. Namun, kekuatan hukum akan lahan hibah ini belum cukup kuat bagi pemerintah daerah, hal itu di karenakan bahwa pernyataan hibah hanya dilakukan pada saat temu masyarakat dengan pemerintah daerah dengan cara lisan dan ditandatangani oleh pemuka masyarakat.

f. Aspek pembiayaan

Dari segi pembiayaan untuk lokasi ini, pemda Kerinci dapat menghemat dana untuk pembelian lahan karena status tanah ini merupakan hibah dari masyarakat tigo Luhah Tanah Sekudung. Sehingga dana untuk pembelian lahan dapat digunakan untuk pembangunan infrastruktur lainnya. 
Dari hasil pengamatan yang penulis lakukan selama penelitian, penulis juga menemukan beberapa fakta dan pertimbangan yang tidak mendapat respon dari pihak pemerintah daerah. Dalam memutuskan lokasi ibukota kabupaten di bukit tengah, pemerintah Kabupaten Kerinci kurang melakukan sosialisasi kepada masyarakat perihal aspek-aspek yang di pertimbangkan dalam menentukan kriteria calon ibukota Kabupaten Kerinci. Hal ini dijelaskan dalam Undang-Undang no 26 tahun 2007 tentang penataan ruang pasal 11 ayat 5 yang berbunyi pemerintah kabupaten/kota harus menyebarluaskan informasi yang berkaitan dengan rencana umum dan rencana rinci tata ruang dalam rangka pelaksanaan penataan ruang wilayah kabupaten/kota dan melaksanakan standar pelayanan minimal bidang penataan ruang.

\section{PENUTUP}

1. Ibukota Kabupaten Kerinci di Bukit Tengah menjadi pilihan oleh pemerintah Kabupaten Kerinci dan DPRD Kabupaten Kerinci karena pertimbangan bahwa lahan seluas $300 \mathrm{Ha}$ ini merupakan lahan hibah oleh masyarakat tigo luhah tanah sekudung.

2. Status hibah tanah merupakan alasan utama mengapa Bukit Tengah dipilih untuk menjadi Ibukota Kabupaten oleh pemerintah kabupaten Kerinci dan DPRD kabupaten Kerinci, namun jika dilihat dari hasil penelitian LAPI ITB, Bukit Tengah sama sekali tidak termasuk dalam daerah nominasi untuk dijadikan Ibukota Kabupaten. Dan dari hasil observasi ke lapangan yang penulis lakukan, Bukit Tengah tidak layak untuk dijadikan Ibukota Kabupaten jika dilihat dari indikator-indikator yang ditetapkan oleh LAPI ITB dan Bappenas.

3. Penetapan Bukit Tengah menjadi Ibukota Kabupaten Kerinci seharusnya perlu dievaluasi kembali, karena masih ada daerah yang lebih layak untuk dijadikan Ibukota Kabupaten Kerinci yang dapat lebih mengoptimalkan fungsi Ibukota Kabupaten sebagaimana mestinya.

4. Dalam penetapan kebijakan oleh pemerintah kabupaten, diharapkan memperhatikan opini-opini yang berkembang di masyarakat. Agar pembangunan Kabupaten Kerinci kedepannya dapat lebih baik lagi dengan memperhatikan aspirasi masyarakat.

5.Sosialisasi sebuah kebijakan nantinya diharapkan dapat disebarluaskan kepada masyarakat, agar masyarakat mengetahui apa-apa saja yang telah diperbuat oleh pemerintah kabupaten Kerinci untuk kemajuan daerah.

6.Dalam menampung aspirasi dari masyarakat, sepertinya diperlukan sebuah forum diskusi yang berlangsung minimal 3 bulan yang diadakan oleh pihak pemda dalam menampung masukan-masukan dari masyarakat. Forum ini nantinya diharapkan mampu mencari jalan keluar dari suatu masalah yang dihadapi, agar dalam setiap pembangunan daerah masyarakat juga ikut merasa bertanggung jawab untuk ikut berperan serta dalam membangun daerah.

7.Pengembangan wilayah di kabupaten Kerinci diharapkan tidak bertumpu hanya pada satu wilayah hierarkis. Melainkan dapat menjangkau seluruh wilayah dengan memperhatikan potensi yang ada disetiap wilayah. Pengembangan ini juga diharapkan sejalan dengan pengawasan terhadap kebijakan-kebijakan yang diterapkan.

\section{DAFTAR PUSTAKA}

Abdurrahman.1998. Beberapa Pemikiran Tentang Otonomi Daerah. Jakarta : Milton Putra 
Makagansa, H.R. 2008. Tantangan Pemekaran Daerah. Yogyakarta: Kuspad.

Undang - Undang NO. 32 Tahun 2004 Tentang Pemerintah Daerah

Pratikno. 2008. "Usulan Perubahan Kebijakan Penataan Daerah (Pemekaran dan Penggabungan Daerah)”. Dalam Jurnal Spirit Publik Volume 1 No 7 Tahun 2011

Bastian, I. 2006. Sistem Perencanaan dan Penganggaran Pemerintah Daerah di Indonesia. Jakarta: Salemba Empat

Kuncoro, M. 2004. Otonomi \& Pembangunan Daerah: Reformasi, Perencanaan, Strategi \& Peluang. Jakarta: Erlangga

Subarsono, AG. 2013. Analisis Kebijakan Publik; Konsep, Teori dan Aplikasi. Yogyakarta: Pustaka Pelajar.

Sugiyono. 2010. Metode Penelitian Kuantitatif, Kualitatif dan R\&D. Bandung: Alfabeta.

Final Report Kajian Ibukota Kabupaten Kerinci, LAPI ITB 